\title{
Olaszország migrációs politikája a 2014-es válság után
}

\author{
Italy's Migration Policy After the 2014 Crisis
}

Kalas Vivien

https://oi.org/10.47707/Kulugvi Szemle.2021.2.5

Összefoglaló: Noha Európa legtöbb országa a tömeges bevándorlás okozta válságot csupán 2015-ben tapasztalta meg, Olaszország partjainál ennél ko rábban, már 2014-ben nagy számban megjelentek az Afrikából útnak indult illegális határátlépők. A migránskérdés a mai napig problémát okoz Olaszor szágban és Európában egyaránt, s már a negyedik különböző színezetủ és összetételű olasz kormány próbál megoldást találni rá. Kutatásomban arra kerestem a választ, hogy az általuk alkalmazott módszerek valóban az ideológiájuktól függenek-e, vagy fellelhető egy olyan stratégia is, amely kormá nyokon átívelőként jellemezhető. A válasz megtalálásához az elmúlt hat év politikai gyakorlatának az áttekintésére és összehasonlítására volt szükség. amelyhez történeti, illetve összehasonlító módszert alkalmaztam. A kutatás eredményeképpen megállapítható, hogy az afrikai államok és az Európai Unió felé képviselt álláspont egységes volt valamennyi ciklusban, különbség csak a belügyi szabályozás terén tapasztalható.

Kulcsszavak: összehasonlító módszer, Olaszország, migráció, kormányzati ciklusok, bevándorláspolitika

Abstract: Though most countries in Europe experienced the crisis caused by the huge influx of migrants only in 2015, a large number of illegal immigrants from Africa have already arrived to the coasts of Italy in 2014. This problem is still relevant today and four different Italian governments have tried to find a solution since 2014. In the research I wanted to explore whether the political practice depended on ideology or there is a strategy that is constant under governments? To the answer, I examined the political practice of the last six years with the help of historical and comparative methods. The research showed that Itab's objectives for Africa and the European Union were the same over the years, only the Italian asylum policy was different.

Keywords: comparative method, Italy, immigration, governments, migration policy 


\section{Külïgyi Szemle}

\section{Bevezetés}

Az Olaszországba érkezỏ küllö̈ldiek száma az 1970-es évek második felétől emelkedett meg jelentősen, mindaddig az elvándorlók aránya bizonyult a magasabbnak. Az első bevándorlási törvény is csupán 1986-ban született meg (Caponio és Graziano, 2011). 2019-ben az ország teljes népességének - 60,3 millió fônek - 8,8 százaléka, vagyis 5,3 millió lakosa származott máshonnan. A legtöbben Romániából, Albániából, illetve Marokkóból költöztek át a mediterrán államba (Tuttitalia.it, n. a.). Az olasz területen jogszerủen tartózkodók számánál azonban sokkal nehezebb megbecsülni azokét, akik a Földközitengeren át, hajóval, illegálisan érkeztek oda.

Az elmúlt néhány esztendőben jelentős mértékben megnöveke dett az Európa - és azon belül is az Európai Unió - határainál megje lenő bevándorlók száma. A biztonságosabb, jobb életben reménykedő, ám sok esetben dokumentummal nem rendelkező emberek egyrészt a Közel-Kelet irányából, másrészt Afrikából indultak el, abban reménykedve, hogy menedékjogra találnak a kontinensen. Olaszország - Európa egyik tengeri határaként - különösen sok menekülttel találta magát szemben, és megoldást kellett találnia a helyzetükre. Míg 2013-ban csupán 43 ezer ember kelt át valamilyen módon a tengeren, addig egy évvel késóbb az olasz hatóságok már több mint 170 ezer afrikai érkezésével szembesülttek (Tanács-Mandák, 2018). E közel 400 százalékos növekedés miatt tekintem a 2014-es esztendôt az olasz migrációs válság kezdetének.

Az elemzésben Matteo Renzi miniszterelnökségének 2014-es kezdetétől 2020 októberéig - vagyis az Európai Bizottság új migrációs és menekültügyi paktumára vonatkozó javaslatának az ismertetését követő hónapig - tekintem át, hogy hogyan változott az illegális határátlépőkkel kapcsolatos olasz politika. Megvizsgálom, hogy milyen döntéseket vonatkoztak az egyes kormányok döntése értelmében azokra, akik már az ország területén tartózkodtak, Róma milyen egyeztetéseket folytatott a különböző afrikai államokkal a bevándorlás megfékezése érdekében, illetve milyen elvárásokat fogalmazott 
meg az Európai Unió felé, és a tagországok a teljesítésük terén menynyire mutatkoztak partnernek. Végezetül kitérek arra, hogy Olaszország számára valóban előrelépést jelent-e az uniós testület legújabb kezdeményezése.

Olaszországnak kezdettől fogva két fơ célja volt, és ahogyan azt a későbbiekben látni fogjuk, a küilönböző kormányokon átívelve, mindvégig azok határozták meg a partnerállamokhoz való viszonyát, valamint a migráció kezelésével kapcsolatos álláspontját. Az egyik, hogy az Afrikából útra kelni szándékozó menekültek közül a lehető legtöbbet a kibocsátó kontinensen tartsanak. Ennek érdekében számos egyeztetést, illetve együttmúködést folytattak és folytatnak - elsősorban Líbiával, ám Tunézia szerepvállalása is felértékelődött az utóbbi időkben. Az olasz politikai vezetés másik prioritása, hogy az Európába érkező bevándorlókkal kapcsolatos problémákat ne kizárólag a frontországoknak kelljen megoldaniuk, hanem e területen is érvényesüljön az európai uniós tagállamok közötti szolidaritás, és valamennyi nemzet vegye ki a részét a migráció kezeléséből. Az viszont, hogy az adott kormány miképpen szabályozta a meneküiltek partszállását és az olaszországi tartózkodását, ciklusonként változott - legfőképpen személyektől, ideológiától füiggően.

\section{A Renzi-kormány migrációs politikája}

Matteo Renzi, a balközép Demokrata Párt (Partito Democratico, PD) politikusa 2014 februárjában, párttársa, a korábbi kormányfő, Enrico Letta lemondását követően lett az ország miniszterelnöke. A posztot csupán 2016 decemberéig töltötte be, mert miután a választópolgárok egy népszavazáson elutasították az alkotmányos reformterveit, úgy döntött, távozik a végrehajtó hatalom éléről. Renzi belügyminiszternek a PD koalíciós partnerének (az akkori nevén: Új Jobbközép) a vezetőjét, Angelino Alfanót választotta, külügyminiszternek pedig a szintén PD-s Paolo Gentilonit tette meg.

Matteo Renzi a hivatalba lépésekor az Olaszországot egyre na gyobb mértékben sújtó tömeges bevándorlás problémáját kapta 


\section{Külïgyi Szemle}

„örökségüil”. A Földközi-tengeren keresztül Európába érkező embe rek elsősorban Líbiából indultak útnak egy jobb élet reményében. A nagy többségüik nem líbiai állampolgárságú volt, hanem nigériai, szenegáli vagy éppen tunéziai, de Marokkóból és Egyiptomon át is nagy számban érkeztek bevándorlók olasz terüiletre. Az elvándorlásuk hátterében több ok is meghúzódik. Az életüket fenyegető fegyveres konfliktusok előli meneküilés mellett a fekete kontinens népességének az egyre gyorsabb ütemű növekedése a másik vezető tényező, hiszen annak hatására a szegénység, az éhezés és a munkanélküiliség mind gyakoribb jelenség a harmadik világ országaiban. Az 1970-es években, az olajválságot követően sokan vállaltak munkát Líbiában a szubszaharai régióból, ám ott a 2010-es esztendők polgárháborúi következtében belpolitikai instabilitás alakult ki, a külföldi állampolgárok pedig nem találtak munkát, és kicsúszott a talaj a lábuk alól. A globalizációs folyamatok eredményeképpen akkor már sokkal több információval rendelkeztek Európáról, az ottani életszínvonalról, így sokan viszonylag hamar rászánták magukat a továbbindulásra. Ezért a migráció kezeléséhez nem csupán belpolitikai szabályozásra volt szüikség, de Renzinek tárgyalnia kellett az afrikai országokkal, illetve az Európai Unióval is.

Az olasz kormányfő afrikai megbeszéléseinek a legfőbb célja az volt, hogy a bevándorlók ne keljenek útra a kontinensről, és ennek érdekében Olaszország kész volt pénzadományok és befektetések révén elősegíteni a migrációt kiváltó okok megszűnését, továbbá hatékony fellépést szeretett volna elérni az embercsempészekkel szemben is. Renzi ezért a hivatalba lépése után nem sokkal, már 2014 márciusá ban Tunéziába látogatott, hogy egyeztetéseket folytasson ottani kollé gájával arról, miképpen lehetne szorosabbra füzni a két ország közötti együittmúködést az illegális bevándorlás terén, továbbá a Földközitenger fokozottabb ellenőrzéséről is megállapodtak (Ansamed, 2014).

Néhány hónappal később, augusztusban az olasz miniszterelnök Egyiptomba utazott, ahol egyebek mellett a líbiai helyzetet is megbeszélte Abdel Fattáh al-Szíszí elnökkel. Renzi aggodalmát fejezte ki amiatt, hogy az arab állam belpolitikai bizonytalansága 
a terrorizmus térhódításának kedvez, és tárgyalópartnere egyetértett vele abban, hogy a stabilitás megteremtése mindannyiuk közös érdeke, hiszen az nem csupán a fegyveres konfliktusoknak vethet véget, de a biztonságos környezet hozzájárulhat az elvándorlás mérséklődésé hez is (RaiNews, 2014). 2016-ban Líbiában nemzetközi támogatással megalakult a nemzeti egységkormány, a vezetője Fájez esz-Szarrádzs lett. A siker azonban nem volt teljes, az ország keleti és déli része ugyanis a nyugalmazott tábornok, Halifa Haftár irányítása alá került. Renzi Róma támogatásáról biztosította a líbiai kormányt, és az illegális bevándorlással összefüiggésben az együittmúködés mihamarabbi kialakítását sürgette (ám az csak a következő kormányzat idején született meg). Ugyanabban az esztendőben az olasz politikai vezetés csapatot küldött Líbiába, hogy kiképezzék az ottani katonai eróket az Iszlám Állam elleni küzdelemhez. A nemzetközi közösség irányvonalától eltérően azt is hangsúlyozták, hogy a terrorizmus visszaszorítása érdekében Haftárral is hajlandóak együttmúködni (Magyar Nemzeti Bank, 2016). E megfontolás húzódhatott meg annak a szándéknak a hátterében is, hogy olasz közvetítéssel mozdítsák elő a két oldal közötti párbeszédet, s azzal segítsék a belpolitikai stabilizációt.

Az olasz döntéshozók mindeközben más afrikai kibocsátó or szágokkal is tárgyalásokat folytattak a migráció elleni harccal kapcsolatosan. Paolo Gentiloni külüigyminiszter a Nigerben, Maliban és Szenegálban tett látogatása során kiemelte, hogy országa az Európai Unió segítségnyújtásán felül pénzügyi forrással is hozzájárul e stratégiailag fontos államokban a határellenőrzés megerősítéséhez és az emberkereskedók elleni küzdelemhez. Nigernek egy 200 millió eurós hitel nyújtására tett ígéretet (Toelgyes, 2016). Az intézkedések azon ban csak ideiglenesen bizonyultak eredményesnek: 2015-ben csök kent ugyan a Földközi-tengeren az olasz partokhoz érkezők száma, ám egy évvel később ismét több mint 180 ezer fő lépett illegálisan a mediterrán állam területére (Statista, 2021).

Az olasz vezetésnek az EU felé folytatott kommunikációját, de a tetteit is a közös válságkezelés és az egységes fellépés szorgalmazása jellemezte. 2014 második felében - júliustól decemberig - Olaszország 


\section{Külïgyi Szemle}

töltötte be az Európai Unió Tanácsának (Tanács) soros elnöki tisz tét, amit Görögországtól vett át, majd a fél év lejárta után Lettor szágnak adott át (így alkották az „elnöki trojkát”). Hagyományosan a tisztséget betöltő tagállam vezeti a tanácsi üléseket, s már idejekorán programokat szervez azokkal a legfontosabb kérdésekkel kapcsolat ban, amelyekre az elnöksége idején küiönös hangsúlyt kíván fektetni. Matteo Renzi és kormánya az előttuik álló hat hónap egyik prioritá saként az illegális bevándorlással szembeni fellépést határozta meg. A céljaik között olyan intézkedések meghozatala is szerepelt, amelyek mind rövid, mind hosszú távon hatékonynak bizonyulnak az ember csempészek és a terrorizmus elleni küzdelemben. Emellett az afrika iaknak nyújtandó anyagi és humanitárius segítséget ugyancsak fontos feladatnak tartották (Parlamento europeo, 2014). Ekkoriban, 2014 no vemberében kezdődött meg az európai uniós tagállamok által létre hozott és olasz irányítás alatt álló Triton művelet. A kezdeményezés célja az volt, hogy az Afrikából menekülőket már a Földközi-tengeren megállítsák és visszafordítsák.

A Triton azonban nem jelentett teljes körű segítséget a Renzi kormánynak, ugyanis a már partot ért bevándorlókkal kapcsolatban eredménytelenül próbált segítséget kérni a többi uniós tagállam tól. A szomszédos Franciaország egyszerúen lezárta a határait a te rületére igyekvő menekültek előtt, az olasz kormányfő pedig hiába érvelt amellett, hogy a migrációs válságra „Brüsszelben, nem pedig Lampedusán kell megoldást találni" (Népszava, 2015). A bevándorlás hoz való viszony azt követően változott meg közösségi szinten, hogy 2015-ben már a görög határnál is megjelentek dokumentumokkal nem rendelkező, a Közel-Keletről útnak indult emberek. Az Európai Bizott ság ennek hatására fogalmazta meg a közös problémakezelés szüksé gességét. Az Európai Tanács egy áprilisi rendkívüli üilésén - az olasz kormány kérésének eleget téve - a döntéshozók megháromszorozták a Triton műveletre fordítható forrás összegét, egy szeptemberi talál kozón pedig a Görögországban és Olaszországban lévő meneküllteknek a tagországok közötti szétosztásáról döntöttek - az egymás iránti szolidaritás elvének megfelelően (Az Európai Unió Hivatalos Lapja, 
2015). Az ülésen a politikusok erről a kérdésről minősített többséggel határoztak, így jogi értelemben nem jelentett akadályt, hogy Magyarország, Csehország, Szlovákia, Finnország és Románia nem támogatta azt. Az Európai Unió emellett anyagi és személyi eróforrást is küldött Olaszországba a menekültkérelmek gyorsabb elbírálásához.

2016-ban a Matteo Renzi vezette kormány egy javaslatot dolgozott ki az Európai Unió lehetséges szerepvállalására vonatkozóan (Italian Government, 2016). Egyebek mellett az afrikai kibocsátó és tranzitországokkal a beruházások és a biztonságpolitika területén való együittmúködés kialakítását, valamint az unió külső határok megerősítését jelölték meg teljesítendő feladatként a közösség számára. Az olasz kormányfő azt javasolta, hogy azoknál a tagállamoknál, amelyek nem kívánják kivenni a részüiket a menekültek áthelyezéséből és a kérelmek elbírálásából, ezt vegyék figyelembe a következő költségvetésből járó támogatások odaítélésekor.

Az uniós országok a bevándorlás ügyében a saját érdekeiket azért helyezhették előtérbe - és az olaszoknak éppen azért volt nehéz dolguk, amikor közös cselekvést sürgettek -, mert nem létezett egységes migrációs politika. 2014-ben - akárcsak ma - két európai egyezmény szolgált a menekülttekkel kapcsolatos szabályozás alapjául. Az egyik a 2008-ban életbe lépett migrációs és menekültügyi paktum volt. A dokumentum aláírói a kölcsönös felelősségvállalás és szolidaritás érvényesülése érdekében célul tűzték ki az illegális bevándorlással szembeni hatékonyabb fellépést, a szabályszegőknek a származási országukba történô visszatelepítését, a határellenőrzés szigorítását, a kibocsátó államokkal való partnerkapcsolatok kialakítását, valamint egy közös menekültüigyi rendszer létrehozását (Council of the Europe an Union, 2008).

Az európai migrációs politika másik alappillérét a dublini rende let (Dublin III) jelenti, amelynek a jelenleg hatályos formáját 2013 ban fogadták el az Európai Unió vezetői, második alkalommal módosítva ezzel az 1990-ben megszületett dublini egyezményt. A politikai döntéshozók e rendeletben rögzítették a nemzetközi védelem iránti kérelmekre vonatkozó eljárásmódot. A jogszabály értelmében a 


\section{Külïgyi Szemle}

menedékkérelmet alapesetben az az állam köteles elbírálni, amelyen keresztüil először lépett be a menedékkérő az Európai Unió területére (Az Európai Unió Hivatalos Lapja, 2013). Az olyan frontországok számára, mint Olaszország, ez problémát jelentett, hiszen a földrajzi elhelyezkedéséből adódóan az Afrikából érkező tömegeknek az olasz partok jelentették az első találkozást Európával. Következésképpen más nemzeteket jogilag semmi sem kötelezte arra, hogy bevándor lókat vegyenek át a mediterrán államtól. Így 2018-ban Olaszország ba érkeztek vissza a legmagasabb számban - több mint hatezer-há romszázan - az úgynevezett „dublini transzferek”, vagyis azok a sze mélyek, akiket más ország küldött vissza az elsődleges helyszínre a dublini rendeletre hivatkozva (Geddes és Pettrachin, 2020, 232. o.). 2019-ben is csupán némileg kevesebb, 5864 bevándorlót kényszerüiltek visszafogadni az olasz hatóságok (Eurostat, 2020).

A migrációt szabályozó 2014-ben hatályos olasz törvények, illetve alacsonyabb szintű jogforrások legfőbb sarokpontjai szerint a mene dékkérelmet az országba érkezést követő nyolc napon belül kellett be nyújtani az illetékes szerveknek. A további dokumentumokat az eljárás során pótlólagosan is bemutathatták. Azok, akik végül nem jogosultak a meneküiltstátuszra, indokolt esetben humanitárius védelemben részesülhettek. Ez utóbbi révén kétéves, de megújítható tartózkodási és munkavállalási engedélyt kaptak az érintettek. A Renzi-kormány ideje alatt érdemben nem változtattak e jogszabályokon. Ugyanabban az évben az olasz törvényhozás alsóháza az illegális olaszországi tar tózkodást bűncselekmény helyett szabálysértésnek kívánta minősíte ni, hogy a bevándorlóval szemben enyhébb eszközökkel lehessen és kelljen fellépniüik a hatóságoknak. Az eljárásmód szerint a legszigo rúbb esetben is csak kiutasítással kellett volna számolni. A szabályozást a kormányzó Demokrata Párt mellett az 5 Csillag Mozgalom (Movimento 5 Stelle, M5S) is támogatta, míg az Északi Liga (Lega Nord) keményebb fellépést követelt (Dömös, 2016). 2016 januárjában azonban a kormány - mivel nem sikerült megszereznie a parlament támogatását a módosításhoz - úgy határozott, hogy továbbra is bűncselekménynek minősül az illegális bevándorlás (Partilodemocratico. it, 2016). 


\section{A Gentiloni-kormány migrációs politikája}

2016 decemberében, Matteo Renzi lemondását követően, a korábbi küilügyminiszter, Paolo Gentiloni lett Olaszország miniszterelnöke. (Egy évvel később az államfő feloszlatta a parlamentet, ám Gentiloni a 2018. júniusi kormányalakításig hivatalban maradt.) Külüigyminisz terének Angelino Alfanót választotta, a belügyi tárcát pedig a Demok rata Párt egyik tagja, Marco Minniti kapta meg. A migráció kezelése terén - az előző politikai gyakorlattal megegyezően - Gentiloni és kormánya is az afrikai országokkal való együittműködésre és a közös európai felelősségvállalás elérésére törekedett.

Olaszország 2017 februárjában két jelentős megállapodást is kö tött: az egyiket Tunéziával, a másikat Líbiával. Tunéziában külüigyminiszteri szinten írtak alá szándéknyilatkozatot arról, hogy a jövőben szorosabbra füzik az együttmúködésüket az embercsempészek elleni küzdelem, a határellenőrzés, valamint a fejlesztéspolitika terén. A líbiai memorandumban ugyancsak az illegális migráció megfékezéséről és a bizonyos beruházások megvalósításáról egyeztek meg a vezetők. Emellett Marco Minniti helyi törzsekkel tárgyalt az ország déli határvédelmének a megerősítésérôl, továbbá Róma anyagi támogatást nyújtott a líbiai parti őrség munkájához is (Colombo és Palm, 2019). Az olasz politikai vezetést - legfőképpen a belïgyminisztert - számos kritika érte civil szervezetek és más politikai szereplők részéról amiatt, hogy a bevándorlók feltartóztatásáért cserébe elnézték a líbiai embertelen körüilményeket.

Minniti a Líbiával szomszédos államba, Nigerbe is ellátogatott, ahol az olaszok a menekültek számára befogadóállomásokat hoztak létre. Az olasz kormány bejelentette, hogy anyagi és katonai erófor rással is hozzájárul ahhoz, hogy az útnak indulók jelentős részét már Nigerben meg lehessen állítani. A pénzügyi forrás biztosítása érdekében 2017-ben létrehozták az Afrika Alapot, amelyen keresztül nem csupán Nigert, de más országokat - Marokkót, Tunéziát vagy éppen Egyiptomot - is segíteni kívánták a terrorizmus és a migráció elleni harcban. Az alap indulótőkéje 200 millió euró volt, ami azonban a 


\section{Külïgyi Szemle}

következő esztendőre jócskán lecsökkent, és akkor már csupán 85 millió euróból tudtak gazdálkodni (Colombo és Palm, 2019).

A Gentiloni-kormány tevékenységének az egyik legfontosabb eredménye, hogy sikerült számottevően csökkentenie a Földközi-tengeren Európába érkezők számát. Míg 2016-ban összesen 181.436 fơ kelt át a tengeren, addig 2017-ben ez a szám 117.153-re csökkent (Statista, 2021). Az előrelépés mégis csak viszonylagosnak tűnt, hiszen az olasz szigetekre kerülő menekültek ellátásának a feladata továbbra is elsődlegesen Olaszországra hárult. Az EU támogatásában bízva a kormányfő ismét Brüsszelhez fordult, s azt kérte, hogy a frissen érkező mentőhajók utasai, illetve a már menekülttáborokban élő bevándorlók befogadásából más nemzetek is vegyék ki a részüiket. Paolo Gentiloni bírálta azokat az országokat, amelyek a segítségnyújtás helyett a határaik lezárása mellett döntöttek.

Az olasz migrációs szabályozás Gentiloni alatt nem változott je lentősen. Csupán a 2017-es magatartási kódex megalkotása jelen tett új elemet - és szinte azonnal kritikát váltott ki sok érintettból. A „Minniti-kódexnek” is nevezett dokumentum a nem kormányzati szervezetek (NGO-k) mentőhajóira vonatkozó elóírásokat tartalma zott. A szabályzat értelmében csak olyan hajó szállíthatott bevándor lókat olasz területre, amelynek a kapitánya aláírta a kódexet. Nekik a mentést a parti őrség irányítása alatt kellett ellátniuk, és nem mehettek be a líbiai felségvizekre (Italian Government, 2017). Az előírásokat az ellenzéki Északi Liga és 5 Csillag Mozgalom is támogatta.

\section{Az elsố Conte-kormány migrációs politikája}

A 2018. márciusi választást követően csak hosszas tárgyalások után, júniusban alakult meg az 5 Csillag Mozgalom és az Északi Liga kormánykoalíciója. Miniszterelnöknek egy pártonkívïli egyetemi oktatót kértek fel, így Giuseppe Conte lett a kormányfő. A belüigyminiszteri posztot Matteo Salvini, az Északi Liga politikusa töltötte be, a külïgyi tárca élére pedig a független Enzo Moavero Milanesi került. Conte a kialakult belpolitikai válság feloldása érdekében 2019 augusztusában lemondott a tisztségéról. 
A Conte-kormány és az elôzô vezetés közötti kontinuitás megmutatkozott az Afrikával és az Európai Unióval kapcsolatos magatartás ban is. A bő egy esztendő alatt folyamatos volt az afrikai államokkal való egyeztetés, amelyek során az olaszok legfontosabb tárgyalópartnere továbbra is Líbia volt. Az EU irányába - ugyancsak a korábbi gyakorlattal összhangban - a kölcsönös felelősségvállalást és a kötelező kvóták bevezetését kommunikálták. A belügyi szabályozás terén azonban jelentős szigorítások történtek.

A két kormány ismét elkötelezte magát a 2008-ban kötött olaszlíbiai barátsági szerződésben foglaltak, többek között az illegális bevándorlás felszámolásának célja mellett. A 2018-as dokumentum értelmében olasz befektetésekért cserébe Líbia meneküllteket fogad vissza az európai mediterrán államtól (Szilágyi, 2018). Róma hasonló egyeztetéseket folytatott más nemzetekkel, például Nigerrel, Tunéziával, illetve Csáddal is. Giuseppe Conte ugyanabban az évben egy, az olasz fővárosban tartandó nemzetközi konferencia rendezését jelentette be, amelyen a különböző szereplőkkel vitatják meg, hogy mikép pen lehetne megteremteni a stabilitást az arab országban. Ugyanezen okból az olaszok azt is sürgették, hogy az ENSZ szüntesse meg a Líbiával szemben érvényben lévő fegyverembargót.

2018 júniusában Conte az uniós miniszterek elé tárt egy javas latot, amelyben kormánya egy többszintű migrációs stratégia lehet séges alapjait fektette le (Italian Government, 2018). Kiemelte, hogy az Európai Unió jövője és hitelessége a fennálló válság kezelésétől függ, valamint hangsúlyozta, hogy széthúzás helyett közös megoldásra van szüikség, amely egyebek mellett magában foglalja a bevándorlóknak a tagországok közötti szétosztását is. A politikai döntéshozók tíz pontban foglalták össze a migrációs probléma strukturális kezelésére vonatkozó meglátásaikat. Alappontként rögzítették, hogy elsőként, a kontinensen belüli más szabályozások kialakítása előtt, az Európába érkezők számát kell csökkenteni. Az olasz javaslat a kibocsátó országokkal való intenzívebb együttmûködést, a küilső határok védelmének megerősítését, a dublini rendszer reformjának szüikségességét, az embercsempészekkel szembeni közösségi szintű fellépést, továbbá a 


\section{Külïgyi Szemle}

kvóták bevezetését tartalmazta. Később egy beszédében Conte álszentséggel vádolta meg az Európai Uniót, amit azzal indokolt, hogy az EU csak beszél a szolidaritás fontosságáról, a gyakorlatban viszont nem juttatja érvényre azt.

Az Olaszország területére lépő meneküiltekre vonatkozó jogszabályok az első Conte-kormány idején nagymértékben szigorodtak a korábbi rendszerekéhez képest. A változtatások kezdeményezése elsősorban Matteo Salvini belügyminiszter nevéhez füződik. Első lé pésként 2018 őszén a parlament elfogadta az úgynevezett Salvinirendeletet (European Council on Refugees and Exiles, 2018). A jogszabályt nemcsak a jobboldali politikai erők, de a koalíciós partner is támogatta. A törvény többek között megszüntette a humanitárius védelem intézményét, és megnehezitette a menekültstátusz megszerzését. Salvini saját hatáskörben megtagadta a kikötési engedélyt egyegy bevándorlókat szállító hajótól is. Így tett 2018-ban az Aquariusszal, amelynek a fedélzetén hatszáz ember utazott, valamint a Diciottival. Ez utóbbi miatt százötven fó nem léphetett olasz földre. A következô esztendőben a civil szervezetek két újabb hajója kényszerüilt várakozásra: akkor az Open Armsnak és a Sea-Watchnak tiltotta meg Salvini - egy 2019 nyarán hozott új kormányrendeletre hivatkozva -, hogy kikössön (Tondo, 2019). A jogszabály az engedély megtagadását ugyanis indokolt esetben belügyminiszteri hatáskörbe sorolta, az azt megszegőkkel szemben pedig akár egymillió eurós bírságot is kiszabhatóvá tett. Az afrikai államokkal folytatott tárgyalások, valamint az újonnan elfogadott rendelet hatásosan csökkentette az illegális határátlépók számát. Már 2018-ban is csupán 23.037 volt azoknak a regisztráltaknak a száma, akik mentőhajóval, illetve csónakkal érkeztek az olasz partokhoz, 2019-ben pedig még ennél is kevesebben, 11.471en jutottak ilyen módon el Olaszországba (Statista, 2021). 


\section{A második Conte-kormány migrációs politikája}

Giuseppe Conte lemondását követően az államfő nem az előrehozott választás kiírása mellett döntött, hanem esélyt kívánt adni annak, hogy tárgyalások révén alakulhasson meg egy új kormánykoalíció. Reményei valóra váltak: 2019 szeptemberében az 5 Csillag Mozgalom és a Demokrata Párt egyezséget kötött, a miniszterelnök pedig ismét Conte lett. Az M5S politikusa, Luigi Di Maio töltötte be a küilüigyminiszteri posztot, a belügyi tárcát pedig a független Luciana Lamorgese vezette. (2021. február 13. óta Mario Draghi vezeti a kabinetet, de a két miniszter továbbra is a tisztségében maradt. A friss kormányra nem tér ki a jelen elemzés.)

Az elmúlt esztendők politikai gyakorlatához hűen, Olaszországnak Conte második kormányzati időszakában is a legfontosabb prioritásai közé tartozott a líbiai belpolitikai stabilizáció, az afrikai országokkal az embercsempészettel és a határok ellenőrzésével kapcsolatos kooperáció, valamint az, hogy Rómának ne egyeduil kelljen viselnie a migráció terhét, hanem más európai uniós nemzetek is vegyék ki a részüket a feladatok ellátásából.

2019 novemberében Lamorgese és a líbiai vezetés felülvizsgálta a Gentiloni-kormány által kötött 2017-es memorandumot, és új elemként többek között a következők kerüiltek bele: az arab ország befogadóállomásain élők körülményeinek a javítása; egy olyan humanitárius folyosó létrehozása, amelyen keresztül a menekültek biztonságban eljuthatnak Európába; Líbia déli határszakaszainak fokozottabb ellenőrzése; valamint az észak-afrikai ország számára juttatandó további segélyszállítmányok küildése (Magyar Hírlap, 2019). A megállapodást a jobb- és a baloldali pártok egyaránt bírálták: a Demokrata Párt képviselői a líbiai kormány kegyetlen bánásmódja feletti szemhu nyást, az Északi Liga pedig a földközi-tengeri út egyszerúbbé tételét kifogásolta.

Tunéziával már a Renzi-kormány idején megkezdődtek az illegá lis bevándorlás megfékezésére irányuló tárgyalások. Az egyeztetések a későbbi olasz kormányok idején is folytatódtak, és Luigi Di Maio 


\section{Külïgyi Szemle}

megígérte az együttmúködés megerősítését és továbbfejlesztését. Célként tủzte ki, hogy nagyobb számú - akár több száz - bevándor ló visszaküldéséről egyezzenek meg. Ahhoz viszont, hogy keveseb ben induljanak el Olaszországba, elengedhetetlen a tunéziai politikai stabilitás és gazdasági fejlődés megvalósítása. 2020 októberében a stratégiailag szintén fontos Nigerrel közösen egy új cselekvési tervet dolgozott ki Róma. Nyolcmillió eurós támogatásért cserébe a nigeri kormány ígéretet tett arra, hogy a hatóságok nagyobb erőfeszítéseket tesznek a területükön feltartóztatott emberek integrálása, a munkavállalási lehetőségek biztosítása, valamint az embercsempészek elleni küzdelem érdekében (InfoMigrants, 2020).

Miután az Északi Liga kikerült a kormányból, enyhülésre lehetett számítani a menedékkérők helyzetével kapcsolatosan. Az előzetes várakozások részben be is igazolódtak, az új vezetés ugyanis 2019-ben egy rendeletet alkotott, amely szerint a menekültkérelmek elbírálását két évről négy hónapra csökkentik, hogy ezzel is rövidítsék a jogtalan olaszországi tartózkodások időtartamát és azzal együtt az ellátási költségeket is (Nyilas, 2019). 2020 őszén pedig egy olyan új migrációs csomagot dolgoztak ki, amelyben erôteljesen lazítottak az addigi sza bályozáson (K. Kiss, 2020). Ennek elemei közül a legfontosabbként a humanitárius védelem intézményének a visszaállítását, illetve a civil szervezetek hajóira kivethető bírság összegének - legfeljebb ötven ezer euróra történő - csökkentését lehet említeni, továbbá a felügye leti jogkör a belïgyminisztériumtól az infrastrukturális és közlekedé si, valamint a védelmi minisztériumhoz került át. 2020 májusában a kormány hatszázezer illegális bevándorlónak adott tartózkodási engedélyt - a lépéssel ismerte el a koronavírus-járvány miatti lezárások idején végzett munkájukat (Origo, 2020). A pandémia miatt azonban az olasz kikötőket is lezárták, s így a hatóságok a nyár folyamán több hajótól is megtagadták a kikötési engedélyt. Az uniós egyeztetéseken Olaszország újfent egy elosztási mechanizmus bevezetését sürgette. A belpolitikai enyhülés az illegálisan érkezők számában is megmutatkozott: az általam vizsgált időszak végéig - vagyis 2020. október 31-éig - 27.207 személy jutott el a Földközi-tengeren az országba 
(Statista, 2020). Látható, hogy a regisztrált illegális határátlépők már az esztendő első tíz hónapjában többen voltak, mint a teljes előző évben.

Az Európai Bizottság (Bizottság) által szeptemberben ismertetett új migrációs és menekuiltuigyi paktumról szóló javaslat a mediterrán ország számára mindenképpen nagy előrelépést jelentett, hiszen végre uniós szinten is elismerték, hogy szükség van egy új szabályozásra. A dokumentumban foglaltak szerint a menedékkérők átvizsgálására már az EU külső határain sor kerülne, a határvédelemre hatékonyabb intézkedéseket dolgoznának ki, a kontinensre érkezőkkel kapcsolatos teendókben pedig minden tagállamnak részt kellene vállalnia. A $\mathrm{Bi}$ zottság azonban nem tenné kötelezővé senkinek sem a befogadást, azt ki lehetne váltani a visszatoloncolásban vagy egyéb szervezési munkában való segítségnyújtással (European Commission, 2020).

Olaszország szempontjából mindebből pozitívumként értékelhető a migráció egységes kezelésének a szándéka, kérdés azonban, hogy a módszernek milyen lenne a hatékonysága, ha az országok túlnyomó többsége a visszaküldésben és nem a befogadásban szeretne részt venni, hiszen a különböző afrikai kormányokkal történt megállapodások ellenére az előbbi egy sokkal lassabb folyamat, és a végrehajtásáig a menekültek továbbra is olasz területen tartózkodnának. A javaslat elfogadásához a Tanács és az Európai Parlament jóváhagyása is szükséges, addig pedig még sok politikai vita várható. A visegrádi országok már jelezték, hogy ebben a formájában nem támogatják a tervezetet.

\section{Összefoglalás}

Olaszországban - a félprezidenciális vagy prezidenciális rendszerekkel ellentétben - a köztársasági elnök a külpolitika terén csupán reprezentatív funkciókat tölt be. Következésképpen - ahogyan azt láthattuk - az állam migrációs politikájának a fö irányvonalait a miniszterelnök, a belüigy- és a külügyminiszter hármasa határozza meg. Az éppen aktuális erőviszonyok személyiségfüggőek. Matteo Renzi idején a kormányfő töltött be hangsúlyos pozíciót a kérdésben, míg a 


\section{Külïgyi Szemle}

Gentiloni-, illetve az első Conte-kormányban a belügyminiszteré volt a főszerep. Marco Minnitinek és Matteo Salvininek egyaránt hatá rozott elképzelései voltak a bevándorlással kapcsolatban, amelyeket érvényre is juttattak. Ehhez segítséget jelentett, hogy Paolo Gentiloni egy visszafogottabb politikát képviselt, Giuseppe Conte pedig párton kívüli volt, így kevesebb mozgástérrel rendelkezett, jobban függött az ôt támogató szervezetek akaratától. A Földközi-tengeren át illegálisan érkezők, valamint a külföldi állampolgárságú, legális határátlépők számának alakulását az 1. táblázat tartalmazza. Az utóbbiba nem tar toznak bele az Európai Unió államaiból Olaszországba költözött polgárok, csupán a vízumköteles országokból érkezők. Az adatokból jól kitűnik a két belügyminiszter tevékenységének az illegális bevándorlás területére gyakorolt hatása. Conte második miniszterelnöki periódusa alatt nem volt kiemelkedő vezéregyénisége a migrációs helyzet ke zelésének.

\section{1. táblázat}

Az illegális és a legális határátlépők számának alakulása,

$$
2014-2019^{1}
$$

\begin{tabular}{|c|c|c|}
\hline Év & $\begin{array}{c}\text { Illegális határátlépők } \\
\text { száma (fô) }\end{array}$ & $\begin{array}{c}\text { Legális határátlépők } \\
\text { száma (fö) }\end{array}$ \\
\hline 2014 & 170.100 & 181.972 \\
\hline 2015 & 153.842 & 188.648 \\
\hline 2016 & 181.436 & 203.157 \\
\hline 2017 & 117.153 & 243.111 \\
\hline 2018 & 23.037 & 231.556 \\
\hline 2019 & 11.471 & 208.836 \\
\hline
\end{tabular}

A felfogásbeli különbségek ugyanakkor jórészt csak az olasz terü leten lévő menekültekkel szembeni fellépésben mutatkoztak meg (szi gorúbb vagy megengedőbb szabályozás formájában), de Olaszország Afrika-politikája, valamint az Európai Unió szerepével összefüggő

1 Forrás: Statista, 2021; Istituto Nazionale di Statistica, 2021. 
álláspontja változatlan maradt a különböző kormányzati ciklusokban. A fekete kontinens államaival mindegyik kabinet az együttmúködésre törekedett - és törekszik - a határvédelem, a stabilitás és az embercsempészek elleni küzdelem érdekében. Ezért az olaszok ma is azon munkálkodnak, hogy megteremtsék Líbia két fele, a nemzeti egységkormány és a Halifa Haftár tábornok vezette erők közötti párbeszéd kereteit. Az EU felé megfogalmazott elvárásaik is állandónak bizonyultak az évek során: a közös felelősségvállalás és az egységes politikai gyakorlat a cél. Noha az olasz táborokban élő, illetve az országba belépni kívánó bevándorlókra vonatkozó szabályozásban voltak ugyan eltérések, abban valamennyi döntéshozó egyetértett, hogy a migránsokra vonatkozóan muszáj valamilyen megoldást találni, és csökkenteni kell a létszámukat.

A 2020. szeptemberi tartományi választásokon a kormánypárti 5 Csillag Mozgalom vereséget szenvedett, a jobboldal pedig erősödött (Kalas, 2020). Giuseppe Conte 2021 elején lemondott, és február óta Mario Draghi a kormányfő. A következő olaszországi parlamenti választás előreláthatóan 2023-ban lesz. Bármilyen eredmény is születik azonban akkor, új megközelítés csupán belügyi vonatkozásban képzelhető el, az elmúlt évek tapasztalatai alapján a partnerországokkal kapcsolatos stratégia változatlan marad.

\section{Irodalomjegyzék}

Ansamed (2014). Mediterranean Not a Border, but the Center of Europe, Italian PM. A letöltés ideje: 2020. október 30. http://www.ansamed. info/ansamed/en/news/nations/tunisia/2014/03/04/Mediterraneanour-future-Renzi-tells-Tunisian-women_10179632.html?idPhoto=2.

Az Európai Unió Hivalalos Lapja (2013). Az Európai Parlament és a Tanács 604/2013/EU rendelete (2013. június 26.) egy harmadik országbeli állampolgár vagy egy hontalan személy által a tagállamok egyikében benyújtott nemzetközi védelem iránti kérelem megvizsgálásáért felelős tagállam meghatározására vonatkozó feltételek és eljárási szabályok megállapításáról. A letöltés ideje: 2020. október 30. https:/eur-lex.europa. eu/legal-content/HU/TXT/PDF/?uri=CELEX:32013RO604\&from=HU. 


\section{Külïgyi Szemle}

Az Európai Unió Hivalalos Lapja (2015). A Tanács (EU) 2015/1601 határozata (2015. szeptember 22.) a nemzetközi védelem területén Olaszország és Görögország érdekében elfogadott átmeneti intézkedések megállapításáról. A letöltés ideje: 2020. október 30. https:/eur-lex. europa.eu/legal-content/HU/TXT/PDF/?uri=CELEX:32015D1601\&fro $\underline{\mathrm{m}=\mathrm{HU}}$.

Caponio, Tiziano és Graziano, Paolo R. (2011). Towards a Security-Oriented Migration Policy Model? Evidence from the Italian Case. In Emma Carmel, Alfio Cerami és Theodoros Papadopoulos (szerk.), Migralion and Welfare in the New Europe. Social Protection and the Challenges of Integration (105-120. o.) A letöltés ideje: 2021. február 25. https:// www.researchgate.net/publication/300775035_Towards_a_securityoriented migration policy model Evidence from the Italian case.

Colombo, Silvia és Palm, Anja (2019). Italy in the Mediterranean. Priorities and Perspectives of a European Middle-Power. Brüsszel: Foundation for European Progressives Studies. A letöltés ideje: 2020. október 30. https://www.feps-europe.eu/attachments/publications/studv $\% 20$ on $\% 20$ the $\% 20$ mediterranean $\% 20-\% 207 \% 20-\% 20$ pp hd.pdf.

Council of the European Union (2008). European Pact on Immigration and Asylum. A letöltés ideje: 2020. október 30. https://register.consilium. europa.eu/doc/srv?l=EN\&l=ST\%2013440\%202008\%20INIT.

Dömös Mariann (2016). Migrációs tendenciák Olaszországban. Belvedere Meridionale, (28), 72-90. DOI: https://doi.org/10.14232/belv.2016.ksz.7.

European Commission (2020). Communication from the Commission on a New Pact on Migration and Asylum. A letöltés ideje: 2020. október 30. https:/eur-lex.europa.eu/legal-content/EN/TXT/?qid=1601287338054 \&uri $=\mathrm{COM} \% 3 \mathrm{~A} 2020 \% 3 \mathrm{~A} 609 \% 3 \mathrm{AFIN}$.

European Council on Refugees and Exiles (2018). Salvini Decree Approved by Italian Senate, amid Citizen's Protests and Institutional Criticism. A letöltés ideje: 2020. október 30. https://www.ecre.org/salvini-decreeapproved-by-italian-senate-amid-citizens-protests-and-institutionalcriticism/.

Eurostat (2020). Incoming 'Dublin' Transfers by Submitting Country (PARTNER), Legal Provision and Duration of Transfer. A letöltés ideje: 2020. október 30. https:/ec.europa.eu/eurostat/databrowser/view/ migr_dubti/default/table?lang=en.

Geddes, Andrew és Pettrachin, Andrea (2020). Italian Migration Policy and Politics: Exacerbating Paradoxes. Contemporary Italian Politics, 12(2), 
227-242. A letöltés ideje: 2021. február 25. https://www.tandfonline. $\mathrm{com} / \mathrm{doi} / \mathrm{full} / 10.1080 / 23248823.2020 .1744918$.

InfoMigrants (2020). Italy to Launch Migration Action Plan in Niger.

A letöltés ideje: 2020. október 30. https:/www.infomigrants.net/en/ post $/ 27975$ italy-to-launch-migration-action-plan-in-niger.

Istiluto Nazionale di Statistica (2021). Migration (Transfer of Residence): Immigrants - Country of Origin. A letöltés ideje: 2021. január 21. http:// dati.istat.it/viewhtml.aspx?il=blank\&vh $=0000 \& v f=0 \& v c q=1100 \& g r a$ ph $=0$ \& view- metadata $=1$ \&lang $=$ en \& QuervId $=9441 \&$ metadata $=$ DCIS MIGRAZIONI\#.

Italian Government (2016). Migration Compact: Contribution to an EU Strategy for External Action on Migration. A letöltés ideje: 2020. október 30. http://www.governo.it/sites/governo.it/files/immigrazione_0.pdf.

Italian Government (2017). Code of Conduct for NGO's Involved in Migrants' Rescue Operations at Sea. A letöltés ideje: 2020. október 30. https:// www.statewatch.org/media/documents/news/2017/jul/italy-eu-sarcode-of-conduct.pdf.

Ilalian Governmenı (2018). European Multilevel Strategy for Migration. A letöltés ideje: 2020. október 30. https://images.politico.eu/wpcontent/uploads/2018/06/Sintesi-migranti-s.pdf.

K. Kiss Gergely (2020). Elkaszálja az olasz kormány Salvini migrációs csomagját. Napi.hu.A letöltés ideje: 2021.január 21. https://www.napi.hu/ nemzetkozi_gazdasag/elkaszalja-az-olasz-kormany-salvini-migracioscsomagjat.714985.html.

Kalas Vivien (2020). Az olasz választásokról. Európa Stratégia Kulatóintézel. A letöltés ideje: 2020. október 30. https:/eustrat.uni-nke.hu/ hirek/2020/09/22/az-olasz-valasztasokrol.

Magyar Hirlap (2019). Líbia beleegyezett a Rómával kötött migrációs szerződés módosításába. A letöltés ideje: 2020. október 30. https:// www.magyarhirlap.hu/kulfold/20191107-libia-beleegvezett-a-romavalkotott-migracios-szerzodes-modositasaba.

Magyar Nemzeli Bank (2016). Olaszország kapcsolata az arab országokkal és Iránnal. A letöltés ideje: 2020. október 30. https://www.mnb.hu/ letoltes/olaszorszag-kapcsolata-az-arab-orszagokkal-es-irannal.pdf.

Népszava (2015). Renzi: Európának nem meghatódnia, hanem cselekednie kell. A letöltés ideje: 2020. október 30. https://nepszava.hu/1068108 renzi-europanak-nem-meghatodnia-hanem-cselekednie-kell. 


\section{Külïgyi Szemle}

Nyilas Gergely (2019). Felgyorsítja az illegális bevándorlók kitoloncolását az olasz kormány. Index. A letöltés ideje: 2021. január 21. https:// index.hu/kulfold $/ 2019 / 10 / 04 /$ felgyorsitja_az illegalis bevandorlok kitoloncolasat az olasz kormanv.

Origo (2020). Döntött a baloldali olasz kormány: legalizálják az illegális migránsokat. A letöltés ideje: 2021. január 21. https:/www.origo.hu/ nagvvilag/20200513-megallapodtak-az-olasz-kormanvpartok-amigransok-letelepiteserol.html.

Parlamento europeo (2014). Le prioritá della Presidenza italiana discusse nelle commissioni parlamentari. A letöltés ideje: 2020. október 30. https:// www.europarl.europa.eu/news/it/press-room/20140722IPR53208/ le-priorita-della-presidenza-italiana-discusse-nelle-commissioniparlamentari.

Parlilodemocratico.il (2016). Reato di clandestinità, Ermini: così non ha senso ma va abolito solo in certi casi. A letöltés ideje: 2020. október 30. https:// www.partitodemocratico.it/giustizia/reato-di-clandestinita-erminicosi-non-ha-senso-ma-va-abolito-solo-certi-casi/? cef_chl_jschl tk -779091c295ceclf623a6d2ec175e491446534557-1620204632-0-AR 9drE400RzS7jPhjOlLLGKB8VfwxkVIYY43rAfueReFidaiWPLO9tHC r6GGgDSFe2xn4Pd-qk31rEnlN32LSHkSolyVWKtPso4OC19kdvYkk mLqmQ7QOwICXfeLSGwha2jnW1vDUXT5ON6JDFGAH7ER Lh tBED3Veu45pT1LmDBOHI5hXSkcubDepdpocko9qp4m5dImE5D FjLOcObXFMVchDwkeEoYUuuoIqLXRlqCEOkqWECl5DEdZhCO HHKLzbUf-sR9ameK-vKw1NH1su44_FhlOuT4gYgOuvfDOEDIGBx 315206vmkJDwkPtnABA VYlivLEH8rJt50J14u3F2Txb8ZB2R12Z MPSsHcfj3sFKRRwIg-JeOKz7gkTY7Ci-fpG8_2MOnsLValSXEgYVSkXxQ-m06COHP6kESS_UEFp9rVH9F4z6SS3RGFzke2fxx66VMZw vZsr77-gpHOFu4mulGms-3YHsDMaiuHgAuGP_YKjd_I-MiU6gA-1Q.

RaiNews (2014). Gaza, Renzi: „L'Italia appoggia la proposta egiziana”. Appello con Al-Sisi per il cessate il fuoco. A letöltés ideje: 2020. október 30. https://www.rainews.it/dl/rainews/articoli/Gaza-Renzi-L-Italiaappoggia-la-proposta-egiziana-1-unica-possibile-per-uscire-dallacrisi-a0210f65-b4ce-409e-a260-48d029754alc.html?refresh ce.

Statisla (2020). Number of Immigrants Who Arrived in Italy from January 2016 to December 2020. A letöltés ideje: 2021. január 21. https://www. statista.com/statistics/765537/number-of-migrants-landed-in-italy/. 
Statista (2021). Number of Immigrants Who Arrived by Sea in Italy from 2014 to 2021. A letöltés ideje: 2021. január 21. https://www.statista.com/ statistics/623514/migrant-arrivals-to-italy/\#statisticContainer.

Szilágyi Károly (2018). Líbiában barátkozik az olasz külügyminiszter. Euronews. A letöltés ideje: 2021. január 21. https://hu.euronews. com/2018/07/08/libiaban-baratkozik-az-olasz-kulugyminiszter.

Tanács-Mandák Fanni (2018). A bevándorlás és az olasz közvélemény. Trendek az elmúlt tíz évben. KKI elemzések (14), 3-12. A letöltés ideje: 2020. október 30. https:/kki.hu/assets/upload/14 KKI-elemzes_ITA Tanacs-Mandak 20180410.pdf.

Toelgyes, Cornelia I. (2016). Il risultato del viaggio di Gentiloni in Africa: contro i migranti finanziamo governi corrotti. Progello Melting Pol Europa. A letöltés ideje: 2020. október 30. https:/www.meltingpot.org/ Il-risultato-del-viaggio-di-Gentiloni-in-Africa-contro-i.html H.X5WX LEo9PY.

Tondo, Lorenzo (2019). Italy Adopts Decree That Could Fine Migrant Rescuers up to 650,000. The Guardian. A letöltés ideje: 2020. október 30. https://www.theguardian.com/world/2019/jun/15/italy-adoptsdecree-that-could-fine-migrant-rescue-ngo-aid-up-to-50000.

Tuttilalia.it (n.a.). Cittadini stranieri in Italia - 2019. A letöltés ideje: 2020. október 30. https:/www.tuttitalia.it/statistiche/cittadini-stranieri-2019/. 